\title{
Jerusalem Artichoke as a Fodder Crop for Food Security Solu- tions
}

\author{
Alexandra Anatolyevna Manokhina ${ }^{1}$, Alexey Semyonovich Dorokhov ${ }^{1}$, Tamara Petrovna Kobozeva ${ }^{1}$, Tatiana Ni- \\ kolaevna Fomina ${ }^{1, *}$ and Oksana Anatolyevna Starovoitova ${ }^{2}$ \\ 1 Russian State Agrarian University - Moscow Timiryazev Agricultural Academy, 127550 Moscow, Russia; \\ alexman80@list.ru (A.A.M.); ikg@rgau-msha.ru (A.S.D.); tkobozeva@rgau-msha.ru (T.P.K.) \\ 2 Russian Potato Research Center, Moscow Region, Russia; coordinazia@mail.ru \\ * Correspondence: tfomina67@mail.ru
}

\begin{abstract}
Topic relevance. Being a valuable source of inulin, fructose and pectin, Jerusalem artichoke (Helianthus tuberosus L.) is one of the most promising bioenergy crops for common usage. Animals have been reported to eat both Jerusalem artichoke green mass and tubers with pleasure. On the one hand, Jerusalem artichoke is cultivated on the area of about 3 thousand hectares in Russia. On the other hand, there are more than 200 crop species. So it is critical to choose a proper variety suitable both for soil and climatic conditions. The purpose of the research is to study Jerusalem artichoke, taking into account varietal characteristics appropriate for forage production. Research objects - varieties of Jerusalem artichoke: early ripening Skorospelka (RF); mid-early Vylgortskiy (RF); mid-season Dieticheskiy (RF), Kaluzhskiy (RF), Korenevskiy (RF), Nadezhda (RF), Nakhodka (RF), Podmoskovniy (RF), Sireniki (RB), Blank Brekos (France), Violet de Rense (France); late ripening Interest (RF), Interest 21 (RF), Novosti VIRa (RF), Tadzhikskiy Krasniy (USSR), Spindle (Germany). The soil for evaluating Jerusalem artichoke varieties was from experimental plot base "Korenevo". It is characterized as sod-slightly podzolic sandy loam. The field trial was established and the records and observations were carried out in accordance with the requirements of the field experiment methodology (1985), and the Program and methodology for evaluating Jerusalem artichoke varieties in test nurseries (2014). The varieties Vylgortskiy, Dieticheskiy, Nadezhda, Nakhodka, Sireniki, Skorospelka, Blank Brekos and Kaluzhskiy were found to reach due height of $155-170 \mathrm{~cm}$ at the end of the growing season; the varieties Podmoskovniy, Interest reached proper height of $175-208 \mathrm{~cm}$; the varieties Interest 21, Tadzhikskiy and Violet de Rense were about 220 - $235 \mathrm{~cm}$ in hight; as for the varieties Korenevskiy, Novost VIRa, Spindly their hight was $270-280 \mathrm{~cm}$. According to aggregate amount of feed units per $1 \mathrm{ha}$, the following varieties have been shown to be the most reasonable for fodder production: Novost VIRa $(22,438$ fodder units), Nadezhda (19,928 fodder units), Korenevskiy (17,798 fodder units), Shpindle (16,887 fodder units), Dieticheskiy (16,395 fodder units), and Interest (16,116 fodder units). The highest total coefficient of energy efficiency has been found in the following varieties: Novost VIRa - 3.09, Tadzhikskiy - 2.78; Spindle - 2.68; Korenevskiy - 2.43; Interest - 2.10; Skorospelka - 1.98. The results of experimental and theoretical studies obtained were verified on-the-farm conditions based on a seed-speciality farm LLC Kaluga-Agro (the Kaluga region) and demonstrated beneficial effect.
\end{abstract}

Keywords: Jerusalem artichoke; green mass; tubers; feed value

\section{Introduction}

Topic relevance. Jerusalem artichoke (Helianthus tuberosus L.) is considered to be one of the most appreciable bioenergetic agricultural crops for general-purpose application, since it is a source of inulin, fructose and pectin [1,2].

Jerusalem artichoke green mass is characterized by a high content of carbohydrate complex (fructose, glucose, sucrose, fructosides, etc.), that makes it possible to obtain up 
to $100 \mathrm{~kg}$ of inulin, 83.2 liters of alcohol, and high-quality feeds per a ton. Plan tdry mass contains up to $17 \%$ protein with a balanced amino acid composition. Introduction of inulin and bioethanol process waste from Jerusalem artichoke into feed composition may provide an increase in the economic efficiency of animal husbandry and guarantee ecological safety of animal products [3,4].

Since the beginning of the twentieth century Jerusalem artichoke has been known in India, Afghanistan, Egypt. As a valuable fodder, food and medicinal crop it has been grown in the USA, Canada, Australia, Japan and some other countries. In 1981 the area under Jerusalem artichoke was 400 hectares in the USA, in 1982 it was equal to 2200 ha, and in 1983 the crops was cultivated on the area upto 60 - 80 thousand hectares. Currently the area under Jerusalem artichoke is globally about 2.5 million hectares, in France, for example, it is almost equal to the area under potato. Despite the shortage of arable land China has intensively been developing the production of Jerusalem artichoke. Jerusalem artichoke is grown as a vegetable crop in many countries, e.g. Italy, Spain, and Germany. It is imported as a vegetable crop in small quantities to Russia as well. [5].

Jerusalem artichoke is cultivated on an area of only about 3 thousand hectares in Russia, mainly in the regions of Nizhny Novgorod, Lipetsk, Tver, Ryazan, Tula, Ulyanovsk, Kostroma, Volgograd, Omsk, Bryansk, Moscow, Saratov, Yaroslavl, as well as, in the Republic of Chuvashia, Krasnodar and Stavropol regions [6,7]. There are more than 200 Jerusalem artichoke species, most of them being herbaceous like sunflowers, some being semi-shrubs, and very few being real shrubs up to $5-7 \mathrm{~m}$ in height [1]. E.I. Stroeva, an individual entrepreneur, the head of the farm in the Kameshkovskiy district, the Vladimir region, is sure that Jerusalem artichoke is a very unpretentious plant $[8,9]$ (Figure 1).

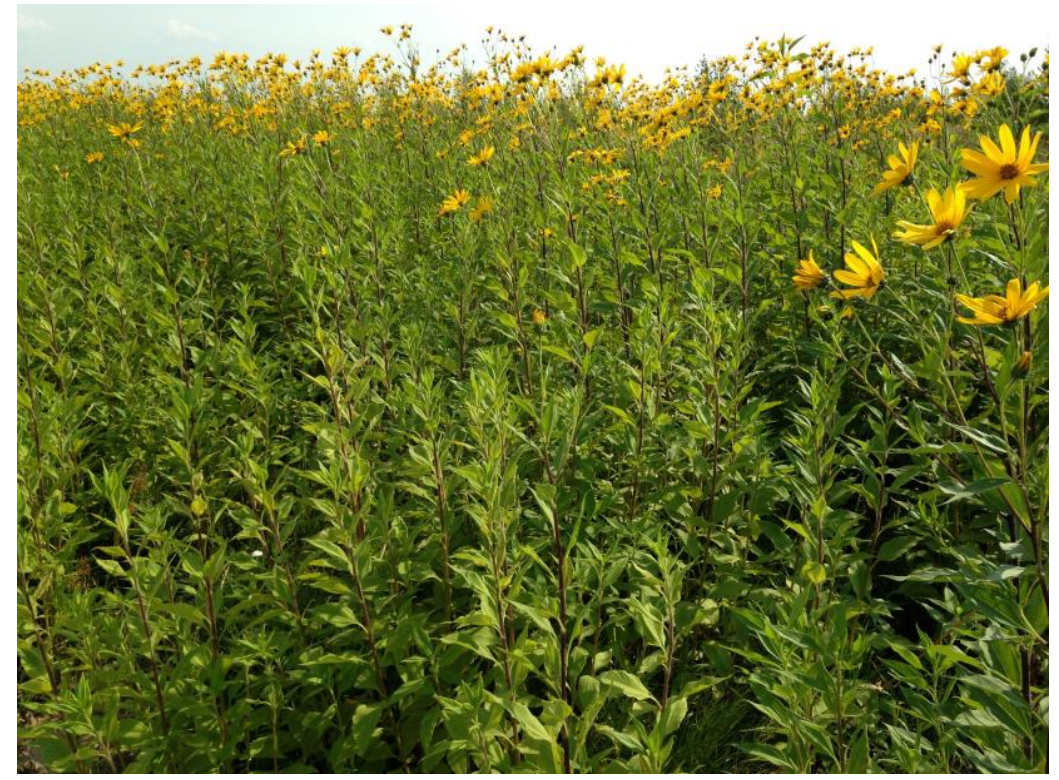

Figure 1. Areas planted with Artichoke at the farm household headed by E.I. Stroeva, an individual entrepreneur (village Serebrovo, Kameshkovskiy district, Vladimir region).

World experience in the cultivation of Jerusalem artichoke has shown that the plant do best in areas with a temperate climate [10,11]. It grows well on different soils, excluding acidic, saline and waterlogged soils. It thrives even on nutrient-poor soils. The plant has a high reproduction rate, frost and drought resistance. It easily tolerates spring frosts and autumn cold snaps [1,12]. Thus it is vital to choose a variety suitable both for soil and climatic conditions. Otherwise a variety that is not adapted to local environments will result in poor quality production and low plant productivity $[13,14]$, as the geographical location of the area for Jerusalem artichoke cultivation is crucial to ensure maximum yield [15]. 
Since Jerusalem artichoke belongs to short-day crops, the productivity of a variety depends on its photoperiodic sensitivity and adaptive ability to local growing conditions. In this regard, the photosynthetic activity of varieties is very different and it also depends on the degree of their short-day duration, as well as on the ecological and geographical conditions of cultivation [16]. The total leaf area of plants is an indicator of the photosynthetic activity and productivity of each variety $[17,18]$.

Young Jerusalem artichoke sprouts can sometimes be damaged by larvae of May beetles and mole crickets, caterpillars of meadow moth. Roots and tubers can be injured by wireworms, false wireworms, May beetle larvae [1].

Animals have been nored to consume readily both Jerusalem artichoke green mass and root crops (Figure 2).
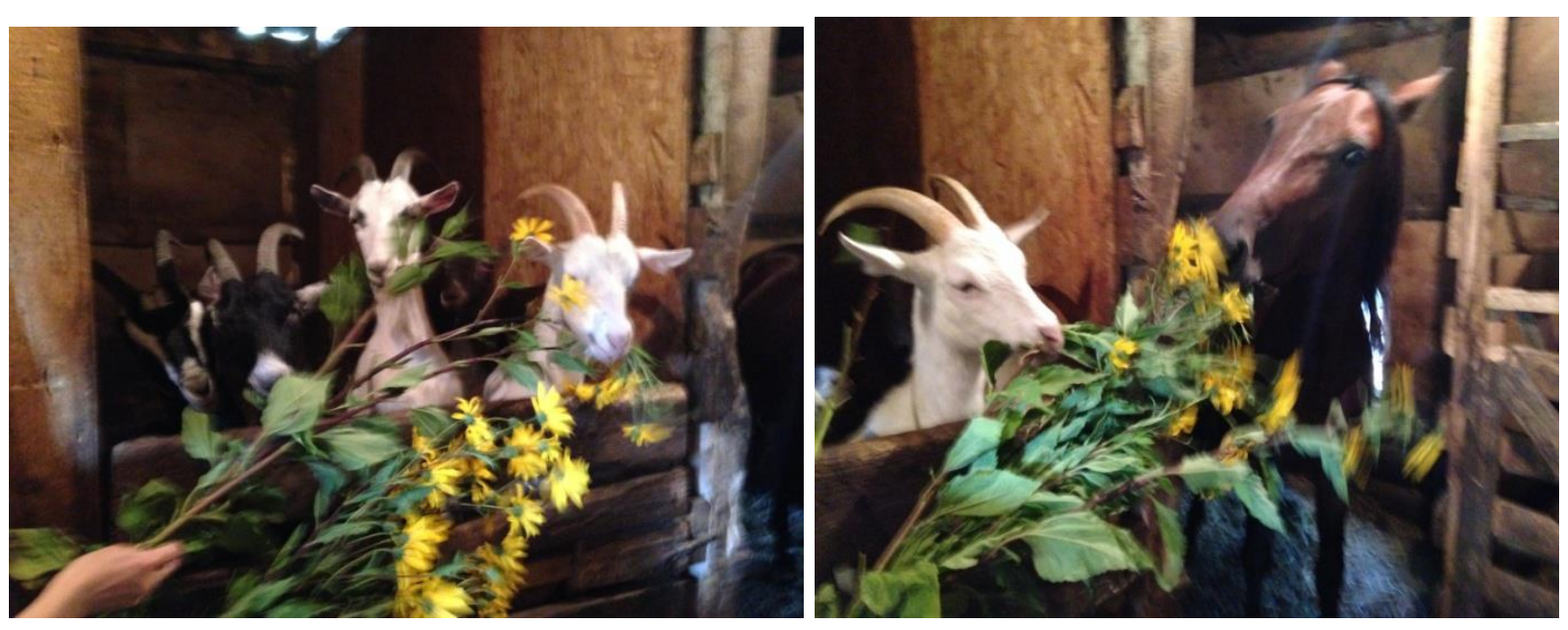

Figure 2. Artichoke green mass is kickshaws (the farm household headed by E.I. Stroeva, an individual entrepreneur (village Serebrovo, Kameshkovskiy district, Vladimir region).

The purpose of the research is to study Jerusalem artichoke, taking into account varietal characteristics suitable for forage production. To achieve this purpose the following tasks were solved: 1) to carry out phenological observations, 2) to measure biometric parameters of different Jerusalem artichoke varieties; 3) to record diseases and pests; 4) to determine green mass morphological characteristics and productivity; 5) to calculate Jerusalem artichoke tuber yields; 6) to find out the value of Jerusalem artichoke as a fodder crop; 7) to investigate the properties of Jerusalem artichoke varietal resources; and 8) to estimate the energy efficiency of Jerusalem artichoke cultivation.

\section{Methodology}

\subsection{Trial field soils}

The Moscow Region is a constituent entity of the Russian Federation and belongs to the Central Federal District. The middle part of the territory of Russia, including the Central, Central Black Earth regions, the Middle Volga region, Western Siberia, the Urals, mountainous regions, despite the wide variety of soil composition and fertility, the amount and uniformity of precipitation, is generally characterized by a relatively moderate background of infectious load and can be considered as a fairly fortunate region for organizing own production of high-quality Jerusalem artichoke for seeds and forage $[19,20]$.

The research results were obtained on the basis of laboratory-field experiments, laid on soils typical for the Non-Chernozem zone of the Russian Federation in terms of their agrophysical and agrochemical properties.

The soil of the field trials site for evaluating Jerusalem artichoke varieties on the experimental base "Korenevo" is characterized (table 1) as sod-slightly podzolic sandy loam with high exchangeable and hydrolytic acidity $(\mathrm{pHKCl}=4.4-4.9 ; \mathrm{Hg}=3.3-4.8$ $\mathrm{meq} / 100 \mathrm{~g}$ of soil); low amount of absorbed bases and saturation degree $(\mathrm{S}=1.5-3.9$ 
meq/100g of soil; $\mathrm{V}=31.0-46.8 \%)$; high content of mobile phosphorus $(267-354 \mathrm{mg} / \mathrm{kg}$ of soil) and below the average content of exchangeable potassium $(95-136 \mathrm{mg} / \mathrm{kg}$ of soil); low humus content (1.6-1.9\% humus).

Table 1. Agrochemical characteristics of sod-slightly podzolic sandy loam soils before field trial establishment.

\begin{tabular}{|c|c|c|c|c|c|c|c|c|}
\hline \multirow[t]{2}{*}{ Years } & \multirow[t]{2}{*}{ рНксІ } & Hг & $S$ & $\begin{array}{l}\text { Sum of } \\
\mathrm{N}-\mathrm{NO}_{3} \\
\mathrm{~N}-\mathrm{NH}_{4}\end{array}$ & $\mathrm{P}_{2} \mathrm{O}_{5}$ & $\mathrm{~K}_{2} \mathrm{O}$ & V & Humus \\
\hline & & \multicolumn{2}{|c|}{$\mathrm{mg} \mathrm{eq} / 100 \mathrm{~g}$ of soil } & $\begin{array}{c}\mathrm{mg} / \mathrm{kg} \text { of } \\
\text { soil }\end{array}$ & \multicolumn{2}{|c|}{$\begin{array}{l}\mathrm{mg} / \mathrm{kg} \text { of soil } \\
\text { (by Kirsanov) }\end{array}$} & \multicolumn{2}{|c|}{$\%$} \\
\hline 2014 & 4.7 & 3.7 & 2.4 & 23.3 & 264 & 127 & 39.3 & 1.8 \\
\hline 2015 & 4.7 & 3.6 & 2.2 & 16.5 & 280 & 100 & 37.9 & 1.7 \\
\hline 2016 & 4.9 & 3.6 & 2.5 & 24.5 & 342 & 64 & 41.0 & 1.7 \\
\hline
\end{tabular}

\subsection{Agrometeorological conditions for conducting research}

The research was carried out during the period of 2014-2016 on the test site of the Experimental base "Korenevo", production tests were carried out in 2016 at LLC "Kaluga Agro" of the Dzerzheyu district of the Kaluga region.

The meteorological conditions during the research years are presented in Figure 3.

The most capacious character of weather conditions is reflected by the hydrothermal coefficient according to Selyaninov (HTC), the value of which is closely related to the yield level. HTC is determined by dividing the precipitation amount for the calculated period by the amount of effective temperatures $\left(10^{\circ} \mathrm{C}\right)$, reduced by 10 times over the same period. Decrease in yield is observed at HTC $=0.8$ or less during the tuberization period. When HTC is more than 3.0, yield decreases are resulted from moisture excess [21].

Agrometeorological conditions during the growing seasons of 2014-2016 were generally satisfactory for Jerusalem artichoke growth, development and productivity. The average air temperature in 2014 was $12.4{ }^{\circ} \mathrm{C}$ (in $2015-12.5^{\circ} \mathrm{C}$, in $2016-12.4{ }^{\circ} \mathrm{C}$ ), with a norm of $11.4^{\circ} \mathrm{C}$. Total precipitation during the growing season in 2014 wasl $300.2 \mathrm{~mm}$ or $73.2 \%$ (in $2015-425 \mathrm{~mm}$ or $103.7 \%$, in $2016-642.3 \mathrm{~mm}$ or $156.6 \%$ ) of the norm $(410.1$ $\mathrm{mm}$ ). Besides HTC in 2014 was 0.97 (dry), in 2015 it was 1.61 (wet), in 2016 it was 2.03 (very wet).

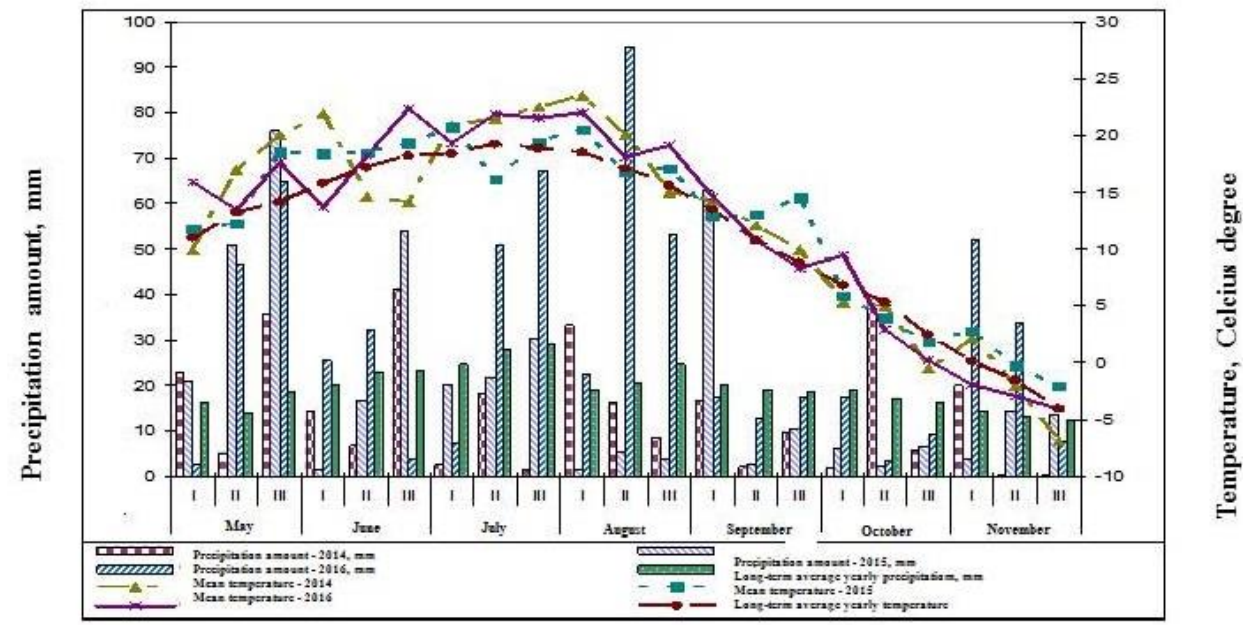

Figure 3. Meteorological conditions during research years (2014-2016) (The data from the Korenevo meteorological station, Lyuberetskiy district of the Moscow region). 


\subsection{Research conditions}

Objects of the research - Jerusalem artichoke varieties [22]: early ripening Skorospelka (RF); mid-early Vylgortskiy (RF); mid-season Dieticheskiy (RF), Kaluzhskiy (RF), Korenevskiy (RF), Nadezhda (RF), Nakhodka (RF), Podmoskovniy (RF), Sireniki (RB), Blank Brekos (France), Violet de Rense (France); late ripening Interest (RF), Interest 21 (RF), Novost VIRa (RF), Tadzhikskiy Krasniy (USSR), Spindle (Germany).

The following operations were done in the studies: 1) disking of green manure crops (vetch + oats) in 2 tracks using an aggregate with a disc harrow in the first ten days of August of the previous year; 2) autumn plowing (first ten-day period of October) - using a unit with a reversible plow without a skimmer to a depth of $18-20 \mathrm{~cm}$; 3 ) spring continuous cultivation with harrowing (second - third ten-day period of April) - using a unit with a continuous cultivator with tooth harrows attachedt; 4) rest-balk formation using a row cultivator with fertilizer dispensers. Calibration and selection of healthy tubers were conducted for seed preparation. Seed tubers of $25-40 \mathrm{~mm}$ in transverse diameter were planted on the test plot using a hand-dropping potato planter to a depth of 8-10 $\mathrm{cm}$.

Field test scheme: repeatability of the experiment -4 times; planting density - 25 thousand pcs./ha $(75 \times 53 \mathrm{~cm})$; accounting plot area $-20.0 \mathrm{~m}^{2}$.

Planting date April 27-30.

Mineral fertilizers in the form of azofoska (N60P60K60) were applied locally in May with two belts using a row cultivator with fertilizer dispensers. The arrangement of the ribbons is about $4 \mathrm{~cm}$ wide, $4-5 \mathrm{~cm}$ in each direction from the center of the rest-balk and by 3-4 $\mathrm{cm}$ below the row of tubers. Planting management included one pre-emergence and one post-emergence inter-row cultivation with hilling using a row cultivator, in May-June. Weed control protective measures on stands were carried out with a boom sprayer - herbicides (the 1st treatment - Zenkor $600 \mathrm{~g} / \mathrm{ha}+$ Titus $30 \mathrm{~g} / \mathrm{ha}+$ Trend 200 $\mathrm{ml} / \mathrm{ha})$, in May.

\subsection{Methodology of field experiments, observations, analyzes and reports}

The field experiment was established, records and observations were carried out in accordance with the requirements of the field experiment methodology [23], the Program and methodology for Jerusalem artichoke varieties assessment in test nurseries [24].

The evaluation of soil agrochemical parameters was fulfilled during the soil field survey meeting the requirements of the Methodology for the soil samples selection on elementary field areas for differentiated use of fertilizers. Agrochemical characteristics of the soil before fertilization were: humus according to Tyurin (Russian National Standard GOST 26,213 - 91); $\mathrm{P}_{2} \mathrm{O}_{5}$ and $\mathrm{K}_{2} \mathrm{O}$ - according to Kirsanov (GOST 26,207 - 91); pH (salt) potentiometrically (GOST 26,483 - 85); hydrolytic acidity - according to Kappen, modified by ZINAO (GOST 26,212 - 91).

Phenological observations were carried out according to the method of the State Sortset. For each variety, the number of days from planting to emergence of shoots, the onset of budding, flowering and complete wilting of the green mass was taken into account [25].

Biometric parameters (plant height, leaf area) were assessed during the flowering phase of early wilt varieties of the aboveground plant parts [26].

Visual infestation registration of Jerusalem artichoke plants. Evaluation of viral and bacterial diseases and pests was carried out on the basis of visual examination of plants in the plot.

Calculation of fungal, bacterial, and viral diseases in the field was carried out according to the method of testing Jerusalem artichoke, similar to the potato testing by the method of samples [23,27]. In the following periods: the first survey was carried out at a plant height of up to $100 \mathrm{~cm}$ (July), the second - in the early flowering phase, and for mid-early varieties (third ten-day period of August - first ten-day period of September), 
the third - in the budding-flowering phase of late varieties (the third ten-day period of October).

Disease analyses were done by examining each plant in the sample (for rust, powdery mildew, cercospora, ascochitosis, bacterial spot, septoria) according to the number of affected plants on a scale: 9 points - no symptoms of damage; 8 points - the lesion can be from $1 \%$ to $10 \%$ of the leaf surface in the form of single spots on individual plants (up to about 10 leaves are affected by infection, in total about 50 spots per plant); 7 points from 10 to $25 \%$ of the leaf surface is affected (damage symptoms can be observed on almost all leaves of the plants, but bushes retain their normal shape, clearly predominant color is green); 5 points - from 25 to $50 \%$ of the surface of plant leaves is affected (almost every plant is affected, but the main color of the bush remains green, although brown spots on the leaves make up a significant part); 3 points - more than $50 \%$ of the leaf area of all plants is affected (it is difficult to determine which color is dominant - brown or green, but the stems of most plants remain green); 1 point - all leaves of the plant are completely affected, the stems are getting dead or have already been dead [28].

The damage to the plants tops by leaf-eating pests was taken into account on a 5point scale: 1 point - up to $5 \%$ of the leaf surface was destroyed; 2 - from 5 to $25 \%$; 3 from 25 to $50 \%$; 4 - from 50 to $75 \% ; 5$ - more than $75 \%$ of the leaf surface was damaged.

For yield valuation two manually weighing of green mass (tubers) from $4-8$ bushes were completed: the first weighting in the flowering phase for early wilting top plant varieties; the second one at the end of October.

In the harvesting samples during the flowering phase of varieties with early plant tops wilting, according to all variants of the experiment, the following findings were determined:

1. Indicators of forage qualities of green mass: maximum plant height, $\mathrm{cm}$; number of main stems, pcs; branching; the thickness of the main stem (at the butt and at a height of $40 \mathrm{~cm}$ ), mm; leaf area, $\mathrm{m}^{2} / \mathrm{bush}$; the amount of green mass, $\mathrm{t}$, in terms of 1 hectare; number of fodder units FU/ha.

2. Productivity of tubers, $\mathrm{t} / \mathrm{ha}$ and indicators of tubers quality [27]: dry matter content - by thermostat-weight method; nitrate content - ionometric (nitratomar-tester); the content of soluble and insoluble substances - by hot water diffusion; carbohydrate content, \% - by liquid chromatography; disease affection of tubers after harvesting.

Tuber analyzes of Jerusalem artichoke were carried out immediately after harvesting.

During the analyses, Jerusalem artichoke was washed in water and each tuber was examined. The number of diseased and damaged tubers was expressed as a percentage of the total number of tubers in the sample. The following diseases on Jerusalem artichoke tubers were taken into account: sclerotinosis, bacteriosis, gray rot, soft rot, and fusarium [29,30]. In case of Jerusalem artichoke, the presence of quarantine diseases is not allowed in the Russian Federation: brown bacterial rot, phomopsis [29,30].

3 Determination of tuber table qualities for fresh consumption (in the flowering phase of early plant top wilting varieties).

Technological qualities of pulp: degree of sweetness; juiciness of the pulp.

Taste qualities of raw pulp on-scale: 1 - bad (unpleasant, bitter); 3 - fresh; 5 - satisfactory (including sweetish); 7 - good; 9 excellent.

Pulp firmness on-scale: 1 - fibrous; 2 - firm; 3 - moderately firm; 4 - soft (gentle).

Smell on-scale: 1 - not typical of Jerusalem artichoke with an unpleasant odor; 3 not typical of Jerusalem artichoke; 5 - poorly expressed, satisfactory (with a slight presence of foreign odor); 7 - poorly expressed, good, without foreign odors; 9 - pleasant, characteristic of Jerusalem artichoke, without foreign odors.

Darkening of the pulp on-scale: 1 - it darkens very strongly; 3 - it darkens strongly over the entire surface; 5 - it darkens moderately; 7 - it darkens slightly; 9 - it does not get dark. 
4 Bioenergetic efficiency analyses of technological methods combination according to the methodology of All-russian scientific research institute of patent informationI (1983) and the bioenergy assessment method [31].

5 Variance analysis of the data obtained according to B.A. Dospekhov [23].

The degree of reliability and implementation of research results. The reliability has been confirmed by the accepted field experiments methodology for 3 research years, the statistical processing results have been obtained by the variance, correlation and regression analyzes.

\section{Results}

\subsection{Phenological observations and biometric parameters of plants.}

During the research experimental procedure for each variety, the number of days from planting to emergence, the onset of budding and flowering phases was taken into account. The time of developmental phases was different for varieties (table 2).

Table 2. Results of phenological observations and biometric indicators records (on average for 2014-2016).

\begin{tabular}{|c|c|c|c|c|c|c|c|c|}
\hline \multirow[b]{2}{*}{$\begin{array}{l}\text { S1. } \\
\text { № }\end{array}$} & \multirow[b]{2}{*}{ Variety } & \multicolumn{5}{|c|}{ Number of days from planting to: } & \multirow[b]{2}{*}{$\begin{array}{c}\text { plant } \\
\text { height, } \mathrm{cn}\end{array}$} & \multirow[b]{2}{*}{$\begin{array}{l}\text { leaf area, } \\
\mathrm{m} 2 / \text { bush }\end{array}$} \\
\hline & & $\begin{array}{l}\text { seed- } \\
\text { lings }\end{array}$ & buddin & $\begin{array}{c}\text { flo- } \\
\text { rescent } \\
\mathrm{e}\end{array}$ & $\begin{array}{l}\text { above- } \\
\text { ground por- } \\
\text { tion wilt }\end{array}$ & $\begin{array}{c}\text { harvest- } \\
\text { ing }\end{array}$ & & \\
\hline 1 & Vylgortskiy & 37 & 106 & 120 & 162 & 176 & 155 & 0.41 \\
\hline 2 & Diyeticheskiy & 37 & 106 & 119 & 161 & 176 & 165 & 0.84 \\
\hline 3 & Interes & 36 & 176 & - & 200 & 176 & 208 & 2.31 \\
\hline 4 & Interes 21 & 36 & - & - & 200 & 176 & 235 & 1.30 \\
\hline 5 & Kaluzhskiy & 35 & - & - & 200 & 176 & 165 & 1.54 \\
\hline 6 & Korenevskiy & 35 & 165 & 176 & 200 & 176 & 280 & 0.93 \\
\hline 7 & Nadezhda & 36 & 108 & 121 & 161 & 176 & 167 & 0.70 \\
\hline 8 & Nakhodka & 35 & 107 & 120 & 162 & 176 & 147 & 0.49 \\
\hline 9 & Novost VIRa & 34 & 170 & - & 200 & 176 & 270 & 1.44 \\
\hline 10 & Podmoskovniy & 36 & 105 & 118 & 160 & 176 & 175 & 1.03 \\
\hline 11 & Sireniki & 35 & 106 & 120 & 162 & 176 & 150 & 0.60 \\
\hline 12 & Skorospelka & 36 & 108 & 118 & 160 & 176 & 170 & 1.00 \\
\hline 13 & Tadzhikskiy & 36 & 176 & - & 200 & 176 & 230 & 2.10 \\
\hline 14 & Blank Brekos & 37 & 107 & 121 & 161 & 176 & 158 & 0.57 \\
\hline 15 & Violet de Rense & 36 & 176 & - & 200 & 176 & 220 & 0.96 \\
\hline \multirow[t]{3}{*}{16} & Shpindel & 34 & 165 & 176 & 200 & 176 & 270 & 1.59 \\
\hline & Average & 36 & 134 & 131 & 181 & 176 & 197.8 & 1.11 \\
\hline & $\mathrm{LSD}_{05}$ & 0.92 & 32.19 & 22.57 & 19.45 & 0.00 & 45.33 & 0.54 \\
\hline
\end{tabular}

\subsection{Evaluation of pest diseases on Jerusalem artichoke plants}

Jerusalem artichoke is affected by pathogens of various etiologies: bacteria, viruses, fungi. Furthermore, plants suffer from nonparasitic functional diseases caused by various environmental factors such as the lack of nutrients, in particular nitrogenous and phosphorus compounds, etc. [32].

4 types of bacteria periodically parasitize and develop as semi-parasites and saprophytes on Jerusalem artichoke in different areas of the distribution area.

No bacterial diseases were found in the samples of our experiments.

Up to the present, Jerusalem artichoke viruses are not widespread, but due to abrupt changes in climatic conditions and associated plant stress the number of viral pathotypes of Jerusalem artichoke may increase. Currently, 9 viral and mycoplasma diseases have been known. They occure in the form of spots, mosaics, curly deformation of 
apical leaves, corrugation of leaf blades, overgrowth and reduction of leaves, deformation of the corolla, and sterility of seeds $[1,29,33]$.

We should mention that no viral diseases were found on Jerusalem artichoke samples in our research.

Powdery mildew practically did not affect the yield of tubers, but negatively affects the quality of green forage and silage (Figure 4). In July, a slight infestation of leaves with downy mildew $1-3 \%$ was noted (Table 3.2). In this case, the plant damage was 1$10 \%$ of the leaf surface in the form of single spots on individual plants, which corresponds to 8 points.

Table 3. Distribution of powdery mildew on Jerusalem artichoke varieties (on average for 20142016), Korenevo, Moscow Region.

\begin{tabular}{ccccc}
\hline \multirow{2}{*}{ S1. № } & \multirow{2}{*}{ Variety } & \multicolumn{2}{c}{ The number of plants affected by powdery mildew, $\mathbf{o}$} \\
\cline { 3 - 5 } & & July & Sept. & Oct. \\
\hline 1 & Vylgortskiy & 1 & 11 & - \\
\hline 2 & Diyeticheskiy & 2 & 9 & 9 \\
\hline 3 & Interes & 1 & 7 & 9 \\
\hline 4 & Interes 21 & 1 & 10 & 24 \\
\hline 5 & Kaluzhskiy & 2 & 4 & 7 \\
\hline 6 & Korenevskiy & 2 & 12 & - \\
\hline 7 & Nadezhda & 1 & 8 & 24 \\
\hline 8 & Nakhodka & 2 & 5 & - \\
\hline 9 & Novost VIRa & 1 & 7 & - \\
\hline 10 & Podmoskovniy & 2 & 12 & 2 \\
\hline 11 & Sireniki & 1 & 15 & - \\
\hline 12 & Skorospelka & 3 & 1 & 3 \\
\hline 13 & Tadzhikskiy & 1 & 14 & 28 \\
\hline 14 & Blank Brekos & 3 & 2 & \\
\hline 15 & Violet de Rense & 2 & 5 & - \\
\hline 16 & Shpindel & 1 & & \\
\hline
\end{tabular}

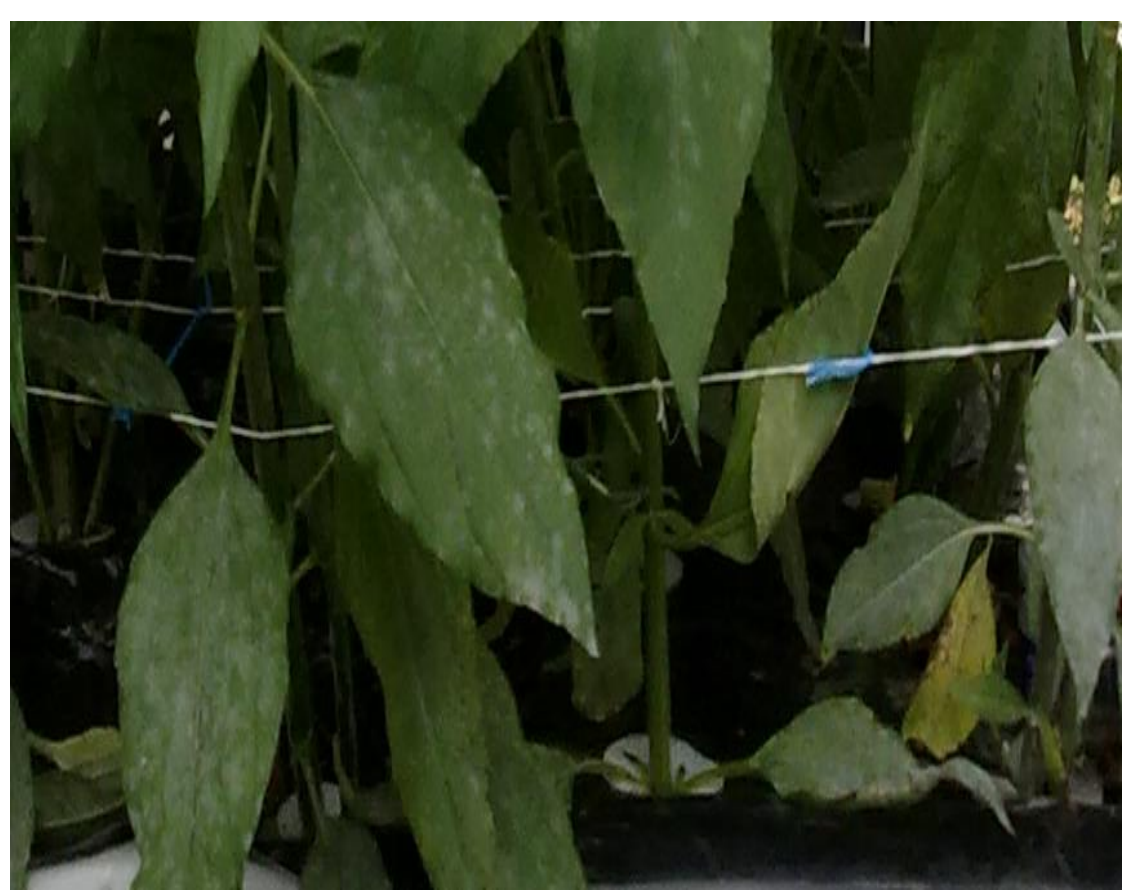

Figure 4. Jerusalem potato affected by powdery mildew. 
The pest infestation assessment was carried out on the basis of a plant visual examination in the registration plot.

Pests on Jerusalem potato collection in 2014-2016:

June: aphids (Aphidoidea) - 0.46 pieces $/ \mathrm{m}^{2}$, cruciferous flea beaver (genus Phyllotreta) - 0.14 pieces $/ \mathrm{m}^{2}$, yellow sawfly (Nematus leucotrochus) - 0.02 pieces $/ \mathrm{m}^{2}$, sunflower moth - Homoeosoma nebulellum Den. et Schiff. - 0.01 pieces $/ \mathrm{m}^{2}$, thrips (Thrips spp.) - 0.01 pieces $/ \mathrm{m}^{2}$, weevil (Tanymecus palliates Fabr.) - 0.006 pieces $/ \mathrm{m}^{2}$, beetle (Rhizotrogus solstitialis) - 0.004 pieces $/ \mathrm{m}^{2}$, spider mite (Tetranychus urticae) $-0.001 \mathrm{pcs} / \mathrm{m}^{2}$.

July: rape bug (Eurydema oleracea L.) - $1.22 \mathrm{pcs} / \mathrm{m}^{2}$, leaf beetles (Chrysomelidae) $0.6 \mathrm{pcs} / \mathrm{m}^{2}$, small moths of various species (Pyralidae family) $-0.27 \mathrm{pcs} / \mathrm{m}^{2}$, moths (family Geometridae) - $0.2 \mathrm{pcs} / \mathrm{m}^{2}$.

\subsection{Green mass morphological characteristics and productivity}

Table 4 depicts stem mass morphological characteristics in the flowering phase of varieties with early top wilting (early September). There were 2-3 pcs/bush of main stems on the "early" varieties, and 1-2 pcs/bush on the "late" varieties.

Table 4. Morphological characteristics of the stem mass.

\begin{tabular}{|c|c|c|c|c|c|}
\hline \multirow[b]{2}{*}{ S1. № } & \multirow[b]{2}{*}{ Variety } & \multirow{2}{*}{$\begin{array}{l}\text { Number, } \\
\text { units }\end{array}$} & \multirow[b]{2}{*}{ Lateral development* } & \multicolumn{2}{|c|}{ Thickness up to..., mm } \\
\hline & & & & at the butt end & $\begin{array}{c}\text { at a height of } \\
40 \mathrm{~cm}\end{array}$ \\
\hline 1 & Vylgortskiy & 2 & much/much** & 12 & 10 \\
\hline 2 & Diyeticheskiy & 3 & 0/much & 23 & 16 \\
\hline 3 & Interes & 3 & 0/much & 31 & 21 \\
\hline 4 & Interes 21 & 1 & 0/much & 29 & 22 \\
\hline 5 & Kaluzhskiy & 1 & 0/much & 32 & 23 \\
\hline 6 & Korenevskiy & 2 & much/much & 14 & 12 \\
\hline 7 & Nadezhda & 2 & much/much & 24 & 19 \\
\hline 8 & Nakhodka & 2 & much/much & 14 & 13 \\
\hline 9 & Novost VIRa & 2 & 0/much & 25 & 21 \\
\hline 10 & Podmoskovniy & 2 & much/much & 22 & 14 \\
\hline 11 & Sireniki & 2 & much/much & 17 & 15 \\
\hline 12 & Skorospelka & 3 & much/much & 27 & 17 \\
\hline 13 & Tadzhikskiy & 3 & 0/not much & 25 & 20 \\
\hline 14 & Blank Brekos & 2 & much/much & 20 & 16 \\
\hline 15 & Violet de Rense & 1 & 0/much & 20 & 18 \\
\hline \multirow[t]{3}{*}{16} & Shpindel & 2 & much/much & 17 & 16 \\
\hline & Average & 2.1 & - & 22.0 & 17.1 \\
\hline & $\mathrm{LSD}_{05}$ & 0.66 & - & 5.94 & 3.65 \\
\hline
\end{tabular}

${ }^{*}$ at the top of the stem/at the bottom of the stem; ${ }^{* *}$ much (more than three).

Total productivity of the artichoke green mass grown on sod-podzolic sandy loam soils under the Korenevo experimental base conditions, Lyubertsy District, Moscow Region, including the one expressed in fodder units per $1 \mathrm{ha}$, has been shown in Table 5 . The reports were carried out in two periods: 1 ) the flowering phase of varieties with early leaf wilting (early September) and 2) the budding-flowering phase of varieties with late leaf wilting (the third ten-day period of October).

Table 5. Total productivity of Jerusalem artichoke green mass, (2014-2016).

\begin{tabular}{lllcccc}
\hline \multirow{2}{*}{$\begin{array}{l}\text { S1. } \\
\text { № }\end{array}$} & Variety & \multicolumn{2}{c}{ Yield, ton per hectare } & \multicolumn{3}{c}{ Fodder units } \\
\cline { 2 - 7 } & Sept. & Oct. & $\begin{array}{c}\text { increase in } \\
\text { yield }\end{array}$ & Sept. & Oct. & average \\
\hline
\end{tabular}




\begin{tabular}{|c|c|c|c|c|c|c|c|}
\hline \multicolumn{8}{|c|}{ Varieties of early leaf wilting ("early variety") } \\
\hline 1 & Vylgortskiy & 24.9 & 18.8 & -6.1 & 5603 & 4230 & 4916 \\
\hline 2 & Diyeticheskiy & 23.6 & 18.1 & -5.5 & 5310 & 4073 & 4691 \\
\hline 3 & Nadezhda & 42.3 & 25.4 & -16.9 & 9518 & 5715 & 7616 \\
\hline 4 & Nakhodka & 13.5 & 13.0 & -0.5 & 3038 & 2925 & 2981 \\
\hline 5 & Podmoskovniy & 28.4 & 19.0 & -9.4 & 6390 & 4275 & 5333 \\
\hline 6 & Sireniki & 32.5 & 19.4 & -13.1 & 7313 & 4365 & 5839 \\
\hline 7 & Skorospelka & 37.6 & 18.7 & -18.9 & 8460 & 4208 & 6334 \\
\hline 8 & Blank Brekos & 34.8 & 14.1 & -20.7 & 7830 & 3173 & 5501 \\
\hline & Group average & 29.7 & 18.3 & - & - & - & - \\
\hline & $\mathrm{LSD}_{05}$ & 8.51 & 3.51 & - & - & - & - \\
\hline \multicolumn{8}{|c|}{ Varieties of late leaf wilting ("late varieties") } \\
\hline 9 & Interes & 53.8 & 53.9 & +0.1 & 12105 & 12128 & 12116 \\
\hline 10 & Interes 21 & 25.3 & 29.2 & +3.9 & 5693 & 6570 & 6131 \\
\hline 11 & Kaluzhskiy & 31.0 & 31.4 & +0.4 & 6975 & 7065 & 7020 \\
\hline 12 & Korenevskiy & 38.4 & 57.3 & +18.9 & 8640 & 12893 & 10766 \\
\hline 13 & Novost VIRa & 86.0 & 86.9 & +0.9 & 19350 & 19553 & 19451 \\
\hline 14 & Tadzhikskiy & 56.5 & 79.3 & +22.8 & 12713 & 17843 & 15278 \\
\hline 15 & Violet de Rense & 23.6 & 28.2 & +4.6 & 5310 & 6345 & 5828 \\
\hline 16 & Shpindel & 65.4 & 80.0 & +14.6 & 14715 & 18000 & 16358 \\
\hline & Group average & 47.5 & 55.8 & - & - & - & - \\
\hline & $\mathrm{LSD}_{05}$ & 20.44 & 22.85 & - & - & - & - \\
\hline & Total average & 38.6 & 37.0 & - & - & - & - \\
\hline & $\mathrm{LSD}_{05}$ & 18.01 & 24.86 & - & - & - & - \\
\hline
\end{tabular}

\subsection{Record of Jerusalem artichoke tubers yield and quality}

For each variety tuber yield was registered in two periods (table 6): the flowering phase of varieties with an early period of top wilting (early September) and the phase of budding-flowering of varieties with a late period of top wilting (the third ten-day period of October).

Table 6. Productivity of Jerusalem artichoke tubers (2014-2016), t/ha.

\begin{tabular}{|c|c|c|c|c|c|c|c|}
\hline \multirow{2}{*}{$\begin{array}{l}\text { S1. } \\
\text { № }\end{array}$} & \multirow{2}{*}{ Variety } & \multicolumn{3}{|c|}{ September } & \multicolumn{3}{|c|}{ October } \\
\hline & & $>30 \mathrm{~mm}$ & $<30 \mathrm{~mm}$ & total & $>30 \mathrm{~mm}$ & $<30 \mathrm{~mm}$ & total \\
\hline \multicolumn{8}{|c|}{ Varieties of early leaf wilting ("early variety") } \\
\hline 1 & Vylgortskiy & 1.9 & 11.5 & 13.4 & 36.0 & 1.5 & 37.5 \\
\hline 2 & Diyeticheskiy & 40.1 & 3.4 & 43.5 & 40.1 & 6.0 & 46.1 \\
\hline 3 & Nadezhda & 11.8 & 29.0 & 40.8 & 41.2 & 4.8 & 46.0 \\
\hline 4 & Nakhodka & 21.2 & 2.1 & 23.3 & 50.3 & 0.8 & 51.1 \\
\hline 5 & Podmoskovniy & 24.4 & 2.1 & 26.5 & 43.5 & 0.9 & 44.4 \\
\hline 6 & Sireniki & 9.3 & 13.8 & 23.1 & 31.1 & 15.8 & 46.9 \\
\hline 7 & Skorospelka & 16.7 & 2.7 & 19.4 & 47.2 & 3.5 & 50.7 \\
\hline 8 & Blank Brekos & 27.1 & 3.7 & 30.8 & 1.9 & $31 ., 2$ & 33.1 \\
\hline & Group average & - & - & 27.6 & - & - & 44.5 \\
\hline & $\mathrm{LSD}_{05}$ & - & - & 9.66 & - & - & 5.83 \\
\hline \multicolumn{8}{|c|}{ Varieties of late leaf wilting ("late varieties") } \\
\hline 9 & Interes & 6.3 & 9.5 & 15.8 & 19.3 & 7.8 & 27.1 \\
\hline 10 & Interes 21 & 7.0 & $6 ., 6$ & 13.6 & 17.7 & 17.8 & 35.5 \\
\hline 11 & Kaluzhskiy & 2.6 & 7.5 & 10.1 & 12,3 & 7.1 & 19.4 \\
\hline 12 & Korenevskiy & 31.7 & 4.2 & 35.9 & 33.0 & 9.9 & 42.9 \\
\hline 13 & Novost VIRa & 0.6 & 11.5 & 12.1 & 24.7 & 0.5 & 25.2 \\
\hline
\end{tabular}




\begin{tabular}{cccccccc}
\hline 14 & Tadzhikskiy & 5.4 & 3.9 & 9.3 & 22.5 & 0.9 & 23.4 \\
\hline 15 & Violet de Rense & 0.0 & 6.0 & $6 ., 0$ & 6.3 & 8.1 & 14.4 \\
\hline 16 & Shpindel & 0.0 & 8.5 & 8.5 & 14.3 & 29.6 & 43.9 \\
\hline Group average & - & - & 13.9 & - & - & 29.0 \\
\hline & LSD 05 & - & - & 8.79 & - & - & 10.08 \\
\hline & Total average & - & - & 20.8 & - & - & 36.7 \\
\hline LSD 05 & - & - & 11.49 & - & - & 11.30 \\
\hline
\end{tabular}

\subsection{The value of Jerusalem artichoke as a forage crop}

Being expressed in fodder units per hectare, the total productivity of various artichoke varieties grown on sod-podzolic sandy loam soils under conditions of the Korenevo experimental base, Lyubertsy District of the MoscowRegion, has clearly been shown in Figure 5.
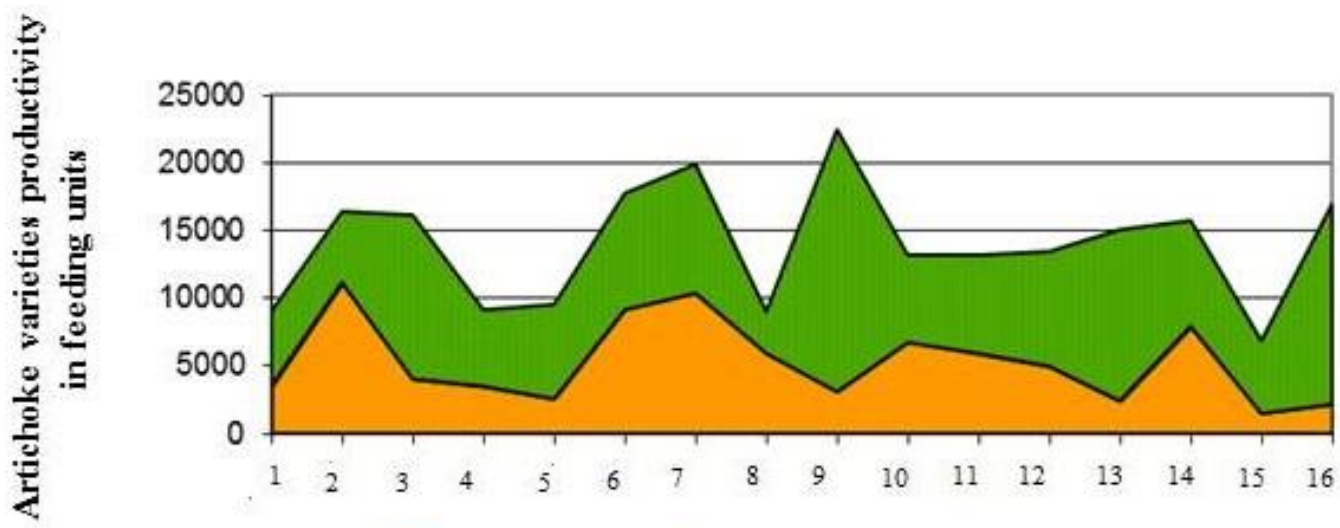

Tubers Green mass

1. Vylgortskiy

2. Diyeticheskiy

3. Interes

4. Interes 21

5. Kaluzhskiy

6. Korenevskiy

7. Nadezhda

8. Nakhodka

\section{Novost VIRa}

10. Podmoskovniy

11. Sireniki

12. Skorospelka

13. Tadzhikskiy

14. Blank Brekos

15. Violet de Rense

16. Shpindel

Figure 5. General productivity of Jerusalem artichoke (green mass + tubers), the 1st ten-day period of September, feeding units.

\subsection{Energy efficiency of Jerusalem potato varieties cultivation}

While calculating the energy efficiency of artichoke varieties (table 7), it is necessary to take into account the yield obtained both of tubers and of green mass, the latter being considered as high-quality animal feeds or full-fledged green manure crops.

Table 7. Energy efficiency of artichoke varieties (2014-2016).

\begin{tabular}{|c|c|c|c|c|c|c|c|c|c|}
\hline $\begin{array}{c}\text { № } \\
\Pi / \Pi\end{array}$ & Variety & $\begin{array}{c}\text { Tuber } \\
\text { yield, ton } \\
\text { per hectare }\end{array}$ & $\begin{array}{l}\text { Energy } \\
\text { costs, } \\
\text { K MJ per } \\
\text { hectare }\end{array}$ & $\begin{array}{c}\text { Energy ob- } \\
\text { tained (tu- } \\
\text { bers), } \\
\text { K MJ per } \\
\text { hectare }\end{array}$ & $\begin{array}{l}\text { Energy ef- } \\
\text { ficiency } \\
\text { coefficient } \\
\text { (tubers) }\end{array}$ & $\begin{array}{c}\text { Green } \\
\text { mass yield, } \\
\text { ton per } \\
\text { hectare }\end{array}$ & $\begin{array}{c}\text { Energy ob- } \\
\text { taned } \\
\text { (green } \\
\text { mass), } \\
\text { K MJ }\end{array}$ & $\begin{array}{c}\text { Total ener- } \\
\text { gy ob- } \\
\text { tained } \\
\text { K MJ }\end{array}$ & $\begin{array}{l}\text { Energy ef- } \\
\text { ficiency } \\
\text { coefficient } \\
\text { (tubers + } \\
\text { tops) }\end{array}$ \\
\hline
\end{tabular}




\begin{tabular}{|c|c|c|c|c|c|c|c|c|c|}
\hline 1 & Vylgortskiy & 37.5 & 36.2 & 40.7 & 1.12 & 24.9 & 19.4 & 60.1 & 1.66 \\
\hline 2 & Diyeticheskiy & 46.1 & 39.4 & 52.7 & 1.34 & 23.6 & 18.4 & 71.1 & 1.80 \\
\hline 3 & Nadezhda & 46.0 & 39.4 & 51.4 & 1.30 & 42.3 & 32.9 & 84.4 & 2.14 \\
\hline 4 & Nakhodka & 51.1 & 41.3 & 56.8 & 1.37 & 13.5 & 10.5 & 67.3 & 1.63 \\
\hline 5 & Podmoskovniy & 44.4 & 38.8 & 48.2 & 1.24 & 28.4 & 22.1 & 70.4 & 1.81 \\
\hline 6 & Sireniki & 46.9 & 39.7 & 45.9 & 1.16 & 32.5 & 25.3 & 71.3 & 1.80 \\
\hline 7 & Skorospelka & 50.7 & 41.2 & 52.2 & 1.27 & 37.6 & 29.3 & 81.5 & 1.98 \\
\hline 8 & Blank Brekos & 33.1 & 34.5 & 41.8 & 1.21 & 34.8 & 27.1 & 68.9 & 2.00 \\
\hline & verage (early) & 44.5 & 38.8 & 48.7 & 1.3 & 29.7 & 23.1 & 71.9 & 1.9 \\
\hline & $\mathrm{LSD}_{05}$ & 5.83 & 2.20 & 5.25 & 0.08 & 8.51 & 6.63 & 7.25 & 0.16 \\
\hline \multicolumn{10}{|c|}{ Varieties of late leaf wilting ("late varieties") } \\
\hline 9 & Interes & 27.1 & 32.2 & 25.7 & 0.80 & 53.9 & 42.0 & 67.7 & 2.10 \\
\hline 10 & Interes 21 & 35.5 & 35.4 & 32.8 & 0.93 & 29.2 & 22.7 & 55.5 & 1.57 \\
\hline 11 & Kaluzhskiy & 19.4 & 29.3 & 25.6 & 0.87 & 31.4 & 24.5 & 50.0 & 1.71 \\
\hline 12 & Korenevskiy & 42.9 & 38.2 & 48.2 & 1.26 & 57.3 & 44.6 & 92.8 & 2.43 \\
\hline 13 & Novost VIRa & 25.2 & 31.5 & 29.6 & 0.94 & 86.9 & 67.7 & 97.3 & 3.09 \\
\hline 14 & Tadzhikskiy & 23.4 & 30.8 & 23.9 & 0.78 & 79.3 & 61.8 & 85.7 & 2.78 \\
\hline 15 & Violet de Rense & 14.4 & 27.4 & 15.0 & 0.55 & 28.2 & 22.0 & 37.0 & 1.35 \\
\hline 16 & Shpindel & 43.9 & 38.6 & 41.1 & 1.06 & 80.0 & 62.3 & 103.4 & 2.68 \\
\hline & Average (late) & 29.0 & 32.9 & 30.2 & 0.9 & 55.8 & 43.5 & 73.7 & 2.2 \\
\hline & LSD 05 & 10.08 & 3.82 & 9.76 & 0.20 & 22.85 & 17.80 & 22.98 & 0.59 \\
\hline & Total average & 36.7 & 35.9 & 39.5 & 1.1 & 42.7 & 33.3 & 72.8 & 2.0 \\
\hline & Total LSD05 & 11.30 & 4.29 & 12.11 & 0.23 & 21.61 & 16.84 & 17.06 & 0.47 \\
\hline
\end{tabular}

\section{Discussion}

\subsection{Phenological observations and biometric parameters of plants}

During the growing season of Jerusalem artichoke plants, the following phenological phases of development were observed: shoots, budding, flowering, tuberization, wilting of the plantaboveground part.

The process intensity of passing the phenological phases of plant development depends on: varietal characteristics, meteorological conditions and agricultural practices. The optimum temperature for germination of Jerusalem artichoke tubers is $18^{\circ}-20^{\circ} \mathrm{C}$. Flowering does best at $20^{\circ}-22^{\circ} \mathrm{C}$. The growth of tubers stops at temperatures below 7 ${ }^{\circ} \mathrm{C}$. The optimum temperature for tuberization is considered to be in the range of $18^{\circ}$ $19{ }^{\circ} \mathrm{C}$. The yield and quality of Jerusalem artichoke are significantly affected by the deviation of soil and air temperature from the optimal values [1,34].

Full shoots of all varieties established in the first ten days of June, i.e. 34-37 days after planting (table 2).

The budding phase in the varieties Vylgortskiy, Dieticheskiy, Nadezhda, Nakhodka, Podmoskovniy, Sireniki, Skorospelka and Blank Brekos began in the second ten-day period of August, that is, 105-108 days after planting, and in the varieties Interest, Korenevskiy, Novost VIRa, Tadzhikskiy, Violet de Rense and Spindle attacked in the second half of October, that is, 165-176 days after planting. For the varieties Interest 21 and Kaluzhskiy, the budding phase did not have time to set in until frost, during which the green mass of plants was frozen, and the processes of plant top development stopped.

The flowering phase in the varieties Vylgortskiy, Dieticheskiy, Nadezhda, Nakhodka, Podmoskovniy, Sireniki, Skorospelka and Blank Brekos began in the third ten-day period of August, that is, 118-121 days after planting, and in the varieties Korenevskiy and Shpindel it started at the end of October, that is 176 days after planting. For varieties Interest, Interest 21, Kaluzhskiy, Novost VIRa, Tadzhikskiy and Violet de Rense, the flowering phase did not have time to begin before frost.

The phase of top wilting in varieties Vylgortskiy, Dieticheskiy, Nadezhda, Nakhodka, Podmoskovniy, Sireniki, Skorospelka and Blank Brekos began in early October, 
that is, 160-162 days after planting, and in varieties Interest, Interest 21, Kaluzhskiy Korenevskiy, Novost VIRa, Tadzhikskiy, Violet de Rense and Spindel started in the second ten-day period of November, that is, 200 days after planting.

Analyzing the data in Table 2 in terms of plant height, it can be noted that the varieties Vylgortskiy, Dieticheskiy, Nadezhda, Nakhodka, Sireniki, Skorospelka, Blank Brekos and Kaluzhskiy reached due height at the end of the growing season - 155 - 170 $\mathrm{cm}$; varieties Podmoskovniy, Interest reached proper height of $175-208 \mathrm{~cm}$; varieties Interest 21, Tadzhikskiy and Violet de Rense - 220 - 235 cm; varieties Korenevskiy, Novost VIRa, Spindel - $270-280 \mathrm{~cm}$.

The area of the assimilation surface of leaves at the beginning of September (table 2) in the varieties Vylgortskiy, Dieticheskiy, Nadezhda, Nakhodka, Sireniki, and Blank Brekos was $0.41-0.84 \mathrm{~m}^{2} /$ bush; Podmoskovniy, Skorospelka, Interest 21, Korenevskiy. Violet de Rense was $0.93-1.30 \mathrm{~m}^{2} / \mathrm{bush}$, varieties Kaluzhskiy, Novost VIRa, Spindel $1.44-1.59 \mathrm{~m}^{2} / \mathrm{bush}$. The greatest area of the assimilation surface of leaves $2.10-2.31$ $\mathrm{m}^{2} /$ bush was in the varieties Interes and Tadzhikskiy.

Therefore, according to the parameters mentioned above, all tested varieties are suitable for use as feed.

\subsection{Analyzing diseases and pests on Jerusalem artichoke plants}

Jerusalem artichoke in different areas of the distribution area were infected by 32 species of phytopathogenic fungi periodically parasitize and develop as parasites, semiparasites and saprophytes. As for pathogens of stems and leaves, the most widespread were: sclerotiniasis (two types of pathogen - sclerotinia sclerotiorum Jerusalem artichoke (Sclerotinia sclerotiorum (Lib,) Mass.) And Sclerotium Rolfsii Sacc.)) Dugg.) And powdery fungi - downy mildew = mildew (Plasmopara helianthi Scaw. Novot/f. Helianthi Novot.) And Powdery mildew (Erysiphe cichoracearum DCF helianthi Jacz.) $[1,35,36]$.

Powdery mildew practically did not affect the tuber yield, but negatively affected the quality of green forage and silage (Figure 4). Among them are plants of early varieties (Skorospelka, Blank Brekos) up to $14-15 \%$ of leaves and mid-early varieties (Vylgortskiy, Nadezhda) up to $11-12 \%$, mid-ripening varieties (Dieticheskiy, Kaluzhskiy, Nakhodka, Podmoskovniy, Sireniki) up to $8-12 \%$. Late-ripening plants (Interest, Interest 21, Novost VIRa, Shpindel) varieties are slightly affected up to $5-7 \%$. The least affected were plants of mid-season varieties (Korenevskiy, Podmoskovniy, Violet de Rense) and late Tadzhikskiy varieties - up to $1-4 \%$ of leaves. In this case, the damage of plants was $1-10 \%$ of the leaf surface in the form of single spots on individual plants, which corresponds to 8 points.

Plants of the following varieties were the most affected by powdery mildew in the 3rd ten-day period of September: Kaluzhskiy, Novost VIRa, Shpindel 24-28\% of leaves. Plants of varieties are slightly affected: Interest, Interest 21, Korenevskiy - $7-.9 \%$. In this case, the damage to plants was $1-10 \%$ of the leaf surface in the form of single spots on individual plants, which corresponds to 8 points. Almost all leaves were clean on varieties: Tadzhikskiy and Violet de Rense - 2 -. $3 \%$.

The average number of plants affected by powdery mildew was $1.6 \%$ in July, $8.0 \%$ in September, and $13.3 \%$ in October. $\mathrm{HCP}_{05}$ was $0.70 ; 4.00 ; 9.72 \%$, respectively. Therefore, if Jerusalem artichoke is grown for green fodder, then it is better to mow the aboveground mass before the 3rd ten-day period of September in order to avoid serious leaf damage due to downy mildew.

As a result, according to these findings, all tested varieties are suitable for use as feed.

Taking into account the damage to the plant tops by leaf-eating pests on a 5-point scale, it was noted that only some plants were damaged, which corresponds to 1 point on-scale - up to $5 \%$ of the leaf surface was injured.

\subsection{Morphological characteristics and productivity of green mass}


Varieties Interes, Interes 21, Kaluzhskiy and Novost VIRa have been found to have a larger diameter of stems at the butt $(25-32 \mathrm{~mm})$; hence, it is more difficult to use the green mass of these varieties in a fresh, unprocessed form (Table 4). In addition, these varieties have smaller tubers in the first ten-day period of September. From this point of view, varieties are more attractive for animals: Vylgortskiy, Korenevskiy, Nakhodka, Podmoskovniy, Sireniki. In the case of repeated mowing without harvesting tubers, these varieties can also be used $[37,38]$.

Varieties Interest, Interest 21, Kaluzhskiy and Novost VIRa are more suitable for processing into pelleted feed, since the aboveground mass of these varieties remains green until the end of October.

In the process of feeding the tubers and green mass of Jerusalem artichoke to animals, it was revealed that there is a significant attraction for all species of animals to Jerusalem artichoke as forage (green mass and tubers) and its preference over other forages $[1,39]$.

Analyzing the data in Table 5, it can be noted that at the end of October, for all "ear$1 y "$ varieties, the value of green mass yield decreased by $0.5-20.7 \mathrm{t} / \mathrm{ha}$ due to drying or almost complete drying of plant tops. At the same time, dry or almost dry "bushes" of Jerusalem artichoke of these varieties can still be used for animal feed.

In terms of the number of feed units per hectare at the beginning of September, the following results were distinguished from the "early" varieties: Nadezhda (9,518 fodder units), Skorospelka (8,460 fodder units) and Blank Brekos (7,830 fodder units). Among the "late" varieties, the largest number of food units was found in the following varieties: Novost VIRa (19,350 fodder units), Shpindel (14,715 fodder units), Interes (12,105 fodder units).

At the end of October, the largest number of feed units was found in the following varieties: Novost VIRa (19,553 fodder units), Shpindel (18,000 fodder units), Tadzhikskiy (17,843 fodder units).

\subsection{Analyzing of Jerusalem artichoke tubers yield and quality}

Being harvested in early September, the yield of tubers with a fraction of more than $30 \mathrm{~mm}$ in transverse diameter in accordance with the requirements (more than $25.0 \mathrm{t} / \mathrm{ha}$ ) was obtained from the following varieties (Table 6): Diyeticheskiy (40.1 t/ha), Korenevskiy (31, 7), Blank Brekos (27.1 t/ha). The yield slightly lower than $25 \mathrm{t} /$ ha was obtained from the following varieties: Nakhodka (21.2 $t / h a)$, Podmoskovniy (24.4 t/ha), Skorospelka (16.7 t/ha).

Jerusalem artichoke is a unique crop which can be used wholly, i.e. all its elements (large tubers, small tubers, stems, leaves, flowers, stolons, roots). Thus, it is important to take into account the yield of tubers not only of the coarse fraction (more than $30 \mathrm{~mm}$ in transverse diameter), but also small tubers (less than $30 \mathrm{~mm}$ ). At the same time, the total (gross) yield in accordance with the requirements (more than $25.0 \mathrm{t} / \mathrm{ha}$ ) was obtained from the following varieties: Diyeticheskiy (43.5 t/ha), Nadezhda (40.8 t/ha), Korenevskiy (35.9), Blank Brekos (30.8 t/ha), Podmoskovniy (26.5 t/ha).

When tubers were harvested in the third ten-day period of October, the yield of tubers with a fraction of more than $30 \mathrm{~mm}$ in transverse diameter in accordance with the requirements (more than $25.0 \mathrm{t} / \mathrm{ha}$ ) was obtained from the following varieties: Nakhodka (50.3 t/ha), Skorospelka (47.2 t/ha), Podmoskovniy (43.5 t/ha), Nadezhda (41.2 t/ha), Dieticheskiy (40.1 t/ha), Vylgortsky (36.0 t/ha), Korenevskiy (33.0 t/ha) ha), Sireniki (31.1 t/ha).

At the same time, the total (gross) yield in accordance with the requirements (more than $25.0 \mathrm{t} / \mathrm{ha}$ ) was obtained on all varieties of early leaf wilting: Nakhodka (51.2 t/ha), Skorospelka (50.7 t/ha), Sireniki (46.9 t/ha), Dieticheskiy (46.1 t/ha), Nadezhda (46.0 t/ha), Podmoskovniy (44.4 t/ha), Vylgortskiy (37.5 t/ha), Blank Brekos (33.1 t/ha), as well as for five varieties of late leaf wilting: Spindel (43.9 t/ha), Korenevskiy (42.9 t/ha), Interest 21 (35.5 t/ha), Interest (27.1 t/ha), Novost VIR (25.2 t/ha). 


\subsection{The value of Jerusalem artichoke as a forage crop}

One of the main objectives of the state program for agriculture development is the worldwide forage production increase. Fodder production is sure to be a fundamental branch of agriculture. The analyses of the scientific and technical state of feed production and animal husbandry in recent years and the prospects for the development of these industries in a market economy have shown that breakthrough innovative solutions are urgent for the successful progress in animal husbandry, fish farming, and domestic animals keeping. In the long term Jerusalem artichoke should become a strategic point for further forage production development in the country, along with grain. The green mass of Jerusalem artichoke must be used for the production of inexpensive, highquality feed, both for large and personal subsidiary plots [40,41].

The aboveground mass of Jerusalem artichoke can be applied for livestock feeding in the form of green top dressing, hay or in silage. Possessing the ability to regrow after grazing, Jerusalem artichoke can also be used as a pasture crop. Green mass in its nutritional value is not inferior and even surpasses other fodder crops [42,43]. The yield of green mass and digestible protein from Jerusalem artichoke per 1 hectare is 2-4 times higher than that of other forage plants. For example, 1 quintal of Jerusalem artichoke green mass contains 22.5 feed units and $1.9 \mathrm{~kg}$ of digestible protein that is 1.5-1.6 times more than in corn. Being high in dry matter and soluble sugar content (in stems and leaves - up to 14\%), it is an excellent raw material for ensiling. Silage from Jerusalem artichoke green mass is second only to corn silage in nutritional value; it surpasses sunflower silage in taste. It is readily eaten by cattle, pigs, sheep, goats and rabbits. So, 100 $\mathrm{kg}$ of such silage contains $1.2 \%$ digestible protein and $17.7 \%$ feed. units, while sunflower silage has $0.8 \%$ and 17.0 feed units, respectively, as to corn $-0.6 \%$ and 19.8 feed units $[1,44,45]$. The value of Jerusalem artichoke as a fodder, vegetable, industrial and medicinal crop is determined, first of all, by the chemical composition of the plant [46,47]. Green mass serves as a source of potassium, magnesium, calcium, etc. [1,48,49]. Jerusalem artichoke tubers and aboveground mass contain a large amount of dietary fiber, protein, amino acids, including essential ones, vitamins, vital macro- and microelements, as well as organic and fatty acids. By the content of magnesium, iron, silicon, zinc, as well as vitamins of $B$ and $C$ group Jerusalem artichoke surpasses potatoes, carrots, beets $[41,50,51]$.

In feeding Jerusalem artichoke tubers and green mass to animals it was revealed that there is a significant attraction for all classes of animals to this crop as a forage (green mass and tubers) and its preference over other forages [52,53].

Animals fed from a very early age with feeds made from Jerusalem artichoke are, on average, three times healthier than everyone else and do not need antibiotics. Jerusalem artichoke increases milk yield by $20-25 \%$, its fat and protein content being improved as well. Jerusalem artichoke is likely to raise the chicken egg production by $10 \%$ and dramatically advance egg taste. But on the other hand, feeding animals with Jerusalem artichoke, it is necessary to keep in mind the usual precautions of transferring animals to new feed, i.e. first, include a little Jerusalem artichoke in the feeding ration, and then increase the dose step by step. Recommended rates for adding Jerusalem artichoke silage to the daily diet are: for cattle - up to $25-45 \mathrm{~kg}$; sheep and goats - up to 3-5 kg; pigs of all ages - up to 3-8 kg; horses - up to $8 \mathrm{~kg}$; rabbits, nutria - up to $0.25 \mathrm{~kg}$; poultry - up to $0.04-$ $0.25 \mathrm{~kg}[1,54]$.

According to the total number of feed units per hectare (Figure 5), the following varieties are considered as the most suitable for fodder production: Novost VIRa (22,438 fodder units), Nadezhda (19,928 fodder units), Korenevskiy (17,798 fodder units), Spindel (16,887 feed units), Dieticheskiy (16,395 feed units), Interest (16,116 feed units).

\subsection{Energy efficiency of Jerusalem artichoke varieties cultivation}

The analyses of main energy assessment indicators of different Jerusalem artichoke varieties tubers (table 7) have shown that with an increase in energy consumption (on average by $5.9 \mathrm{MJ} / \mathrm{ha}$ ) in case of growing varieties with early green mass wilting (com- 
pared with late green mass wilting varieties), the amount of energy received also increases (on average by $18.5 \mathrm{MJ} / \mathrm{ha}$ ). The energy efficiency ratio increased by an average of 0.4 .

Despite the low tubers yield of Novost VIRa, the highest total energy efficiency coefficient of 3.09 was obtained, since this variety had the highest yield of green mass. The total coefficient of energy efficiency was slightly lower in the varieties: Tadzhikskiy 2.78; Spindle- 2.68; Korenevskiy - 2.43. The highest total coefficient of energy efficiency among varieties with early green mass wilting was found in varieties: Nadezhda - 2.14; Blacn Brekos - 2.00; Skorospelka - 1.98 .

Thus, Jerusalem artichoke is one of the most promising crops and its cultivation is economically feasible.

\section{Conclusion}

1. The soil and climatic conditions of the Central Federal District meet Jerusalem artichoke growing requirements and allow obtaining high-quality seeds, high yields of green mass and tubers.

2. There are no reliable data on Jerusalem artichoke varieties characteristics. Our studies will let us give a preliminary assessment of Jerusalem artichoke varieties grown in the Central Federal District. This will be useful for growers in choosing a variety to start growing Jerusalem artichoke for forage purposes.

3. Varieties Vylgortskiy, Dieticheskiy, Nadezhda, Nakhodka, Sireniki, Skorospelka, Blank Brekos and Kaluzhskiy reached due height at the end of the growing season - 155 - $170 \mathrm{~cm}$; varieties Podmoskovniy, Interest reached proper height of $175-208 \mathrm{~cm}$; varieties Interest 21, Tadzhikskiy and Violet de Rense - 220 - $235 \mathrm{~cm}$; varieties Korenevskiy, Novost VIRa, Spindle - $270-280 \mathrm{~cm}$. The maximum value of the leaf apparatus assimilation surface have been formed by the varieties with early green mass wilting by the end of flowering: Interest $-2.3 \mathrm{~m}^{2} /$ bush, Tadzhikskiy, Kaluzhskiy $-2.1 \mathrm{~m}^{2} / \mathrm{bush}$, Spindle 1.6 $\mathrm{m}^{2} /$ bush, Novost VIRa and Podmoskovniy $-1.4 \mathrm{~m}^{2} /$ bush, Skorospelka $-1 \mathrm{~m}^{2} /$ bush .

4. Jerusalem artichoke plants are disease resistant. The main diseases that appeared at the end of the growing season (powdery mildew) did not significantly affect the yield.

5. For the consumption of green mass in fresh, unprocessed form, varieties with thin stems are more attractive: Vylgortskiy, Korenevskiy, Nakhodka, Podmoskovniy, Sireniki.

6. The highest gross yield of tubers was obtained in the following varieties: Nakhodka (51.2 t/ha), Skorospelka (50.7 t/ha), Sireniki (46.9 t/ha), Dieticheskiy (46.1 t/ha), Nadezhda (46.0 t/ha), Podmoskovniy (44.4 t/ha), Spindle (43.9 t/ha), Korenevskiy (42.9 $\mathrm{t} / \mathrm{ha})$, Interest 21 (35.5 t/ha), Vylgortskiy (37.5 t/ha), Blank Brekos (33.1 t/ha), Interest (27.1 t/ha), Novost VIRa (25.2 t/ha).

7. According to the total number of fodder units per 1 ha, the following varieties were distinguished: Nadezhda (30.346 fodder units), Novost VIRa (22.438 fodder units), Korenevskiy (17.798 fodder units), Spindle (16.887 fodder units), Dieticheskiy (16.395 feed units), Interest (16.116 feed units).

8 . The highest total coefficient of energy efficiency was found in the following varieties: Novost VIRa - 3.09, Tadzhikskiy - 2.78; Spindle - 2.68; Korenevskiy - 2.43; Interest 2.10; Skorospelka - 1.98 .

9. The results of experimental and theoretical studies obtained were checked onthe-farm conditions based on a seed-speciality farm LLC Kaluga-Agro (the Kaluga region) and proved positive effect results of the research.

10. Thus, Jerusalem artichoke is one of the most promising crops and its cultivation is economically feasible.

\section{References}

1. Korolev, D.D. Potatoes and Jerusalem artichoke - products of the future/D.D. Korolev, E.A. Simakov, V.I. Starovoitov//M., FSSI "Rosinformagrotech". 2007. - 292 p.

2. Abramchuk, A.V. Jerusalem artichoke productivity in relation to planting dates/A.V. Abramchuk, V. R. Laptev//Agrarian Bulletin of the Urals. - 2009. - No. 12. - pp. 39-40. 
3. Anikienko, T. I. Chemical and trace element composition of Jerusalem artichoke tubers and green mass/T. I. Anikienko//Bulletin of KrasSAU. - 2008. - No. 2. - pp. 76-80.

4. Zelenkov, V. N. Jerusalem artichoke (Helianthus tuberosus) perspective multipurpose crop/V. N. Zelenkov, N. K. Kochnev, T. V. Shelkova. - Novosibirsk : Aris, 1993. - 36 p.

5. Ilchenko, S. M. Market trends of Jerusalem artichoke and its processed products/S. M. Ilchenko, O. Y. Patlasov//Bulletin of the Omsk State Agrarian University. - 2016. - No. 1. - pp. 261-266.

6. Zelenkov, V. N. Jerusalem artichoke (Helianthus tuberosus L.). Report 1. Biological aspects of plant development in nature and on the territory of Russia (literature review)/V. N. Zelenkov//Bulletin of the Russian Academy of Sciences. - 2017. - No. 2. - pp. 71-78.

7. Starovoytov V., Starovoytova O., Aldoshin N., Manohina A. Jerusalem artichoke as a means of fields conservation//Acta Technologica Agriculturae. 2017. Vol. 20. № 1. pp. 7-10. Scientific article. English ISSN: 1335-2555 eISSN: 1338-5267 Vol.: 20 №: 1 2017m pp 7-10 DOI: 10.1515/ata-2017-0002

8. Usanova, Z.I. Productivity of Jerusalem artichoke grown on technogenically polluted soils/Z.I. Usanova, M.N. Pavlov//Modern problems of science and education. - 2014. - No. 6. - 1654 p.

9. Ruban, G. A. Jerusalem artichoke as perennial crop in the North (Komi Republic)/G. A. Ruban, K. S. Zainullina, Zh. E. Mikhovich//Bulletin of the Botanical Garden of Saratov State University. - 2019. - No. 4. - pp. 212-224.

10. Starovoitov, V.I., Starovoitova, O.A., Aldoshin, N., Manokhina, A.A. Technology and mechanization of cultivation of Jerusalem artichoke healthier//Research in Agricultural Engineering 2018. 64(3), pp. 151-156

11. Safarmadi, M. Productive potential of Jerusalem artichoke (Heliautus tuberosus 1.) Tajikistan/M. Safarmadi, K. Partoev, I. S. Nigmanov//proceedings of the Orenburg state agricultural university. - 2020. - No. 4. - pp. 82-85.

12. Zhangabaev, A. S. Effect of cultural practices on Jerusalem artichoke yields in Karakalpakstan/A. S. Zhangabaev, R. F. Mavlyanova//International scientific review. - 2017. - No. 5. - pp. 15-17.

13. Manokhina A.A., Starovoitova O.A., Starovoitov V.I. Improving the technological process for the mini-tubers production of the original seed of Jerusalem artichoke//In the collection: IOP Conference series: Earth and environmental science. The conference proceedings. 2019. p. 012091

14. Variety analysis of Jerusalem artichoke under the conditions of the taiga zone of Western Siberia/V. V. Khristich, V. N. Kumpan, N. A. Prokhorova [et al.]//Bulletin of Omsk State Agrarian University. - 2015. - No. 4. - pp. 19-23.

15. Kochnev, N. K. Jerusalem Artichoke - bioenergetic crop of the XXI century/N. K. Kochnev, M. V. Kalinicheva. - Moscow : ARIS, 2002. - 76 p. 66. Krivoshapkin, K. K. Artichoke - a promising forage and food plant for Yakutia/K. K. Krivoshapkin, F. A. Lukin//Academic Bulletin of the Yakut state agricultural academy. - 2020. - No. 9. - pp 29-36.

16. Steinbauer, C. E. Effects of temperature and humidity upon the length of rest period of tubers of Jerusalem artichoke (Helianthus tuberosus)/C. E. Steinbauer//Proc. Amer. Soc. Hort. Sci. 29. - 1932. - pp. 403-408.

17. Moshou, D. Automatic detection of 'yellow rust' in wheat using reflectance measurements and neural networks/D. Moshou, C. Bravo, J. West, A. McCartney, H. Ramon//Comput. Electron. - Agric. 44 (3). - 2004. - pp. 173-188.

18. Onyango, C.M. Segmentation of row crop plants from weeds using color and morphology/C.M. Onyango, J.A. Marchant//Comput. Electron. Agric. 39. -2003. - pp. 141-155.

19. Zhangabayeva, A. S. Influence of seed material on the growth, development and yield of Jerusalem artichoke tubers under Karakalpakstan conditions/A. S. Zhangabayeva, R. F. Mavlyanova//Young scientist. - 2017. - No. 32. - pp. 29-31. - URL: https://moluch.ru/archive/166/45352/(date of reference: 05.08.2019).

20. Zhuchkova, M. A. Jerusalem Artichoke - a plant of the XXI century/M. A. Zhuchkova, S. G. Skripnikov//Vegetables of Russia. - 2017. - No. 1. - pp. 31-33.

21. Zhorovin N. A. Growing conditions and consumer qualities of potatoes/N. A. Zhorovin//Minsk: Urajay, 1977. - 94 p.

22. GOST R 55757-2013 Jerusalem artichoke (tubers). Seed piece. Varietal and planting qualities. General technical conditions.

23. Dospekhov, B.A. Methodology of field trial (with the basics of statistical processing of research results)/B.A. Dospekhov. $5^{\text {th }}$ revised edition - M.: Agropromizdat. - 1985. - 351 p.

24. Starovoitov, V.I. Program and methodology for evaluating Jerusalem artichoke varieties in test nurseries within the framework of the implementation of the program of the Union State "Innovative development of potatoes and Jerusalem artichoke" for 2014 - 2016/V.I. Starovoitov, O.A. Starovoitova, Yu.P. Boyko, Yu.A. Masyuk, S.D. Kiru, M.I. Yaroshevich. Brochure. M. SSI Russian Potato Research Center of the Russian Agricultural Academy. - 2014- - 6 p.

25. Methodology of state variety testing of agricultural crops. Issue 1. General part/State Commission on Variety testing of agricultural crops under the Ministry of Agriculture of the USSR; comp. Yu. A. Rogovsky [et al.] ; edited by A.M. Fedin. - Moscow : [B. I.], 1985. - 194 p.

26. Nichiporovich, A.A. Methodological guidelines for recording and control of the most important indicators of the crop photosynthetic activity processes in planting/A.A. Nichiporovich, M, Nauka, 1967- - 143 p.

27. Conducting methods of tests for distinctness, uniformity and stability. The State Commission of the Russian Federation for Testing and Protection of Breeding Achievements. 02/20/2012. No. 12-06/82.

28. Malko, A.A. Technological process of original and reproductive seed potato production//A.A. Malko, Yu.N. Nikolaev, V.S. Makarova, etc.//Moscow: Federal State University "Rosselkhoznadzor", SSI Russian Potato Research Center of the Russian Agricultural Academy Rosselkhoznadzor Academy, 2011. - 32 p.

29. Dunin, M.S. Diseases and pests of Jerusalem artichoke/Sb. tr. All-Russian SRI of leguminous crops directed by M.S. Dunin//M.: 1935 Vol..VI . issue 1- - 204 p.

30. Phytosanitary diagnostics in integrated plant protection. - M. Kolos, - 1995. 
31. Litun, B.P. Methodology of bioenergetic assessment in potato production/B.P. Litun. - M.: SSI Russian Potato Research Center of the Russian Agricultural Academy. - 2000. - 30 p.

32. Koroleva, Yu. S. Yields and crop structure of Jerusalem artichoke during long-term cultivation in the Upper Volga region/Yu. S. Koroleva//Biological features of medicinal and odoriferous plants and their role in medicine: a collection of scientific papers based on the materials of the International scientific and Practical conference dedicated to the $85^{\text {th }}$ anniversary of All-Russian Scientific Research Institute of Medicinal and Aromatic Plants (June 23-25, 2016; Moscow). - Moscow : Shcherbinskaya Printing House, 2016. - pp. $239-243$.

33. Sadykov, B. K. Cultivation of Jerusalem artichoke (Heliantus tuberosus) under various environmental conditions/B. K. Sadykov//Bulletin of the Al-Farabi Kazakh National University. - 2009. - No. 1. - pp. 89-97.

34. Ustimenko, G. V. Jerusalem artichoke/G. V. Ustimenko. - Moscow: Selkhozgiz, 1960. - 100 p.

35. Skoblina, V. I. Jerusalem Artichoke/V. I. Skoblina. - Moscow: ArmadaPress, 2001. - 36 p.

36. Yaruk, I. V. Monitoring of pathogen development on Helianthus tuberosus L./I. V. Yaruk//Youth in science 2017: proceedings of the International Conference of Young Scientists (October 30 - November 2, 2017; Minsk). - Minsk : Publishing house of the Belarusian science, 2018. - pp 363 - 367.

37. Danilov, K. P. Collection of Jerusalem artichoke leaf-stem mass and tubers harvesting depending on harvesting time and fertilizer/K. P. Danilov, L. V. Kashkarov//Vestnik of Ulyanovsk state agricultural Academy. - 2013. - No. 3. - pp 10-14.

38. Koroleva, Yu. S. Accumulation of Jerusalem artichoke green mass and tubers yield in the Upper Volga region/Yu. S. Koroleva//Digitalization in agri business: technological resources, new opportunities and challenges: a collection of scientific papers based on the materials of the International Scientific and Practical Conference (February 11-13, 2020; Tver)/Tver State Agricultural Academy. - Tver : Tver State Agricultural Academy, 2020. - pp. 15-19.

39. Kuznetsov, A. F. Pigs: maintenance, feeding and diseases/A. F. Kuznetsov. - St. Petersburg : Lan, 2007- - 544 p.

40. Revnivtsev, P. V. Jerusalem artichoke (Heliautus tuberosus) - innovative multi-purpose crop/P. V. Revnivtsev, Ya. V. Vedina//Young scientists - agriculture: a collection of articles based on the materials of the student conference (April 11-12, 2017; Saratov)/Saratov State Agrarian University. - Saratov : Saratov State Agrarian University, 2017. - pp. 21-25.

41. Tsuglenok, N. V. Jerusalem artichoke as a high-energy fodder crop in the feed production of the Krasnoyarsk Territory/N. V. Tsuglenok, G. I. Tsuglenok, T. I. Anikienko//Bulletin of the Krasnoyarsk State Agrarian University. - 2007. - No. 4. - pp. 127130.

42. Anikienko, T. I. Chemical composition and nutritional value of Jerusalem artichoke green mass and tubers in comparison with other crops/T. I. Anikienko//The successes of modern natural science. - 2015. No. 9, part 2. - pp. 278-282.

43. Jaboeva, A. S. Biochemical composition of Jerusalem artichoke/A. S. Jaboeva, L. G. Shaova//proceedings of the Kuban state University. - 2016. - No. 14. - pp. 648-653.

44. Kotova, Z. P. Nutrient value evaluation of Jerusalem artichoke (Heliantus tuberosus 1.) in Karelia/Z. P. Kotova, N. V. Parfenov//Kormoproizvodstvo. - 2015. - No. 6. - pp. 41-45.

45. Titok, V. Jerusalem artichoke - a multifunctional crop/V. Titok, A. Veevnik, M. Yaroshevich//Science and innovation. - 2014. No. 5. - pp. 26-28.

46. Kays, S.J. Genetic variation in Jerusalem artichoke (Helianthus tuberosus L.) flowering date and duration/S.J. Kays, Kultur, F.//HortScience. - 40. - 2005. - pp. 1675-1678.

47. Kolomeichenko, V. V. Fodder production: textbook/V. V. Kolomeichenko. - St. Petersburg : Lan, 2015. - 656 p.

48. Razumov, V. A. Mass analysis of feeds: handbook/V. A. Razumov. - Moscow : Kolos, 1982. - 176 p.

49. Tsgoeva, T. E. Chemical analysis of Jerusalem artichoke varieties Skorospelka and Interest/T. E. Tsgoeva//Izvestiya Gorsky SAU. - 2011. - No. 2. - pp. 280-282.

50. Yaschuk, M. A. Jerusalem artichoke as raw materials for compound feeds production/M. A. Yaschuk, E. V. Solovyova//News of higher educational institutions. Food technology. - 2007. - No. 7. - pp. 57-58.

51. Yaroshevich, M. I. Jerusalem artichoke (helianthus tuberosus L.) - a perspective crop/M. I. Yaroshevich, N. N. Evening, A.V. Gorny//Theoretical and applied aspects of plant introduction as a promising direction for the development of science and national economy: a collection of papers based on the materials of the International Scientific Conference dedicated to the $75^{\text {th }}$ anniversary of the formation of the Central Library of the National Academy of Sciences of Belarus (June 12-15, 2007; Minsk). Minsk : Edith VV, 2007. - vol.1 - pp. 323-325.

52. Mikhalchenkova, E. S. Jerusalem artichoke as a promising fodder crop in the Non-Chernozem zone of Russia/E. S. Mikhalchenkova//Bulletin of the OrelSAU. - 2009. - No. 2. - pp. 42-43.

53. Pazin, M. A. Prospects for the cultivation of non-traditional fodder crops (Jerusalem artichoke) under conditions of the Kemerovo region/M. A. Pazin, Yu. V. Kuznetsov//Modern trends in agricultural production in the world economy: proceedings of the XVIII International Scientific and Practical Conference (December 3-4, 2019; Kemerovo)/Kuzbass State Agricultural Academy. - Kemerovo: Kuzbass State Agricultural Academy, 2019. - pp. 78-82.

54. Khaziakhmetov, F. S. Rational feeding of animals: a textbook/F. S. Khaziakhmetov. - 3rd ed., ster. - St. Petersburg: Lan, 2019- 364 p. - URL : https://e.lanbook.com/book/115666 (accessed: 05.08.2019). 